\title{
Beneficial effects of ginger (Zingiber officinale) on carbohydrate metabolism in streptozotocin-induced diabetic rats
}

\author{
Nafiu Bidemi Abdulrazaq ${ }^{1 *}$, Maung Maung $\mathrm{Cho}^{2}$, Ni Ni Win ${ }^{3}$, Rahela Zaman ${ }^{1}$ and \\ Mohammad Tariqur Rahman ${ }^{1}$ \\ ${ }^{1}$ Department of Biomedical Science, Faculty of Science, Jalan Istana, Bandar Indera Mabkota, 25200 Kuantan, Malaysia \\ ${ }^{2}$ Department of Basic Medical Science, International Islamic University Malaysia, Jalan Istana, Bandar Indera Mahkota, \\ Kuantan, Pahang 25200, Malaysia \\ ${ }^{3}$ School of Pharmacy and Health Sciences, International Medical University, Kuala Lumpur, Malaysia
}

(Submitted 30 June 2011 - Final revision received 2 November 2011 - Accepted 2 November 2011 - First published online 12 December 2011)

\begin{abstract}
Zingiber officinale (ZO), commonly known as ginger, has been traditionally used in the treatment of diabetes mellitus. Several studies have reported the hypoglycaemic properties of ginger in animal models. The present study evaluated the antihyperglycaemic effect of its aqueous extract administered orally (daily) in three different doses $(100,300,500 \mathrm{mg} / \mathrm{kg}$ body weight) for a period of $30 \mathrm{~d}$ to streptozotocin (STZ)-induced diabetic rats. A dose-dependent antihyperglycaemic effect revealed a decrease of plasma glucose levels by 38 and $68 \%$ on the 15 th and 30th day, respectively, after the rats were given $500 \mathrm{mg} / \mathrm{kg}$. The $500 \mathrm{mg} / \mathrm{kg}$ ZO significantly $(P<0 \cdot 05)$ decreased kidney weight (\% body weight) in ZO-treated diabetic rats $v$. control rats, although the decrease in liver weight (\% body weight) was not statistically significant. Kidney glycogen content increased significantly $(P<0.05)$ while liver and skeletal muscle glycogen content decreased significantly $(P<0 \cdot 05)$ in diabetic controls $v$. normal controls. ZO $(500 \mathrm{mg} / \mathrm{kg})$ also significantly decreased kidney glycogen $(P<0 \cdot 05)$ and increased liver and skeletal muscle glycogen in STZ-diabetic rats when compared to diabetic controls. Activities of glucokinase, phosphofructokinase and pyruvate kinase in diabetic controls were decreased by 94,53 and $61 \%$, respectively, when compared to normal controls; and ZO significantly increased $(P<0.05)$ those enzymes' activities in STZ-diabetic rats. Therefore, the present study showed that ginger is a potential phytomedicine for the treatment of diabetes through its effects on the activities of glycolytic enzymes.
\end{abstract}

Key words: Zingiber officinale: Carbohydrate metabolism: Diabetic rats: Tissue glycogen

Ginger rhizomes are widely used in foods for their nutritional and medicinal benefits, especially in $\mathrm{Asia}^{(1)}$; for example, as a source of $\mathrm{Fe}$ and $\mathrm{Ca}$ for women during the post-natal period and also for treating morning sickness and other gastrointestinal disorders ${ }^{(2)}$. More recently, ginger juice was shown to have an antidiabetic effect in alloxan-induced diabetic rats ${ }^{(1)}$. In a similar study, ginger juice was reported to cause significant reduction in the fasting glucose levels and an increase in the insulin levels in streptozotocin (STZ)-induced type 1 diabetic rats $^{(3)}$. Al-Amin et al. ${ }^{(4)}$ also found that ginger possesses hypoglycaemic, hypocholesterolaemic and hypolipidaemic potential. They showed, in addition, that raw ginger was effective in reversing proteinuria in diabetic rats ${ }^{(4)}$.

Though a subsection of non-insulin-dependent diabetes mellitus patients can be managed by diet alone, most patients require an oral hypoglycaemic agent such as insulin. Insulin therapy affords effective glycaemic control, yet its shortcomings such as ineffectiveness on oral administration, short shelf-life, requirement of constant refrigeration and in the event of excess dosage, fatal hypoglycaemia, limit its usage. Treatment with sulphonylurea and biguanides is also associated with side effects ${ }^{(5)}$.

In addition, studies on the hypoglycaemic properties of ginger in animals have reported variable results ${ }^{(4,6,7)}$ and there has been no report on the effect of ginger extract on the selected glycolytic enzymes involved in carbohydrate metabolism. Therefore, the present study was undertaken to determine the effectiveness of ginger (Zingiber officinale (ZO) Roscoe) in the treatment of diabetes mellitus using animal models, by investigating its effect on the key enzymes of carbohydrate metabolism, which shows its beneficial effect in correcting the nutritional disturbances in diabetes.

Abbreviations: DCNT, diabetic control rats; $\mathrm{LD}_{50}$, lethal dose 50\%; NCNT, normal control rats; PK, pyruvate kinase; STZ, streptozotocin; ZO, Zingiber officinale.

*Corresponding author: N. B. Abdulrazaq, fax +6095716781, email nafiurazaq@gmail.com 


\section{Materials and methods}

\section{Animals}

Male Sprague-Dawley rats (body weight $250-300 \mathrm{~g}$ ) were acclimatised inside a room at $22 \pm 2^{\circ} \mathrm{C}$ for a period of $7 \mathrm{~d}$. All animals were fed with standard rat chow in the form of pellets and animals described as fasting were deprived of food for at least $16 \mathrm{~h}$ but were allowed to drink filtered tap water. The standard rat chow containing carbohydrate $4.7 \%$, protein $18.9 \%$ and fat $3.5 \%$ was purchased from Liaz Bhd. The total energy content of the chow was $17.7 \mathrm{~kJ} / \mathrm{g}$. All handling and management procedures were carried out in accordance with the Guidelines for the Care and Use of Laboratory Animals of the Kulliyyah of Medicine, International Islamic University Malaysia (IIUM).

\section{Preparation of the rhizome extract}

Fresh ginger was bought from the wet-market of Chow Kit, Kuala Lumpur; and $2.0 \mathrm{~kg}$ of the fresh ginger rhizomes were cut into pieces, air-dried and powdered. Then, $375 \mathrm{~g}$ of the powdered material were cold-macerated in 4 litres of distilled water and intermittently stirred thoroughly. The mixture was left at room temperature for $48 \mathrm{~h}$ to allow the active ingredients to be completely dissolved. The macerated pulp was first filtered by mesh cloth and then suction-filtered through Whatman no. 1 filter paper and the filtrate was freeze-dried. To increase the shelf life and uniformity, the extract was lyophilised completely by a continuous freeze-drying operation for $54 \mathrm{~h}$ and the yield was $25 \cdot 3 \%(\mathrm{w} / \mathrm{w})$, which was stored at $-20^{\circ} \mathrm{C}$ until use.

\section{Acute toxicity test ( $L D_{50}$ determination)}

The acute toxicity test (lethal dose $50 \% ; \mathrm{LD}_{50}$ ) of the aqueous extract of ginger was determined according to the procedure described by Lorke ${ }^{(8)}$. This method involved an initial dosefinding procedure, in which animals were divided into three groups of three animals per group. Doses of 10, 100 and $1000 \mathrm{mg} / \mathrm{kg}$ of ginger extract were administered through oral administration, one dose for each group. The treated animals were monitored for $24 \mathrm{~h}$ for mortality. Even the highest dose of $1000 \mathrm{mg} / \mathrm{kg}$ was not found to be toxic to the animals. So, the next round of toxicity test was conducted with four different doses of $800,1600,3200$ and $6400 \mathrm{mg} / \mathrm{kg}$, which were administered orally to four groups of one rat per

Table 1. Acute toxicity test of the aqueous extract of ginger*

\begin{tabular}{lcc}
\hline Doses $(\mathrm{mg} / \mathrm{kg})$ & No. of animals & No. of deaths/group \\
\hline Stage I & 3 & $0 / 3$ \\
10 & 3 & $0 / 3$ \\
100 & 3 & $0 / 3$ \\
1000 & & \\
Stage II & 1 & $0 / 1$ \\
800 & 1 & $0 / 1$ \\
1600 & 1 & $0 / 1$ \\
3200 & 1 & $1 / 1$ \\
6400 & 1 & \\
\hline
\end{tabular}

$\mathrm{LD}_{50}$, lethal dose $50 \%$.

${ }^{*} \mathrm{LD}_{50}=(3200 \times 6400)^{1 / 2}=4525.5 \mathrm{mg} / \mathrm{kg}$. group. The treated animals were again monitored for $24 \mathrm{~h}$. The $\mathrm{LD}_{50}$ was then calculated as the geometric mean of the lowest dose showing death and the highest dose showing no death (Table 1).

\section{Induction of diabetes}

Animals were divided into five different treatment groups (Table 2). Body weights were measured after a $16 \mathrm{~h}$ fasting period. The animals in groups 2-5 were lightly anaesthetised with diethyl ether and were injected intraperitonially with $65 \mathrm{mg} / \mathrm{kg}$ body weight of STZ which was freshly dissolved in citrate buffer with a $\mathrm{pH}$ of $4 \cdot 5$. After injection, they were allowed free access to food and water and were given $5 \%$ glucose solution to drink overnight to counter the hypoglycaemic shock. Then, $3 \mathrm{~d}$ after STZ injection, diabetes was confirmed in rats by measuring the normal fasting blood glucose levels with a glucometer (Roche Accu-Check Advantage). All rats showing a fasting blood glucose level $\geq 13 \mathrm{mmol} / \mathrm{l}$ were considered diabetic and selected for the experimentation.

\section{Experimental design}

Table 2 shows the experimental design. Normal control animals in group 1 received distilled water only. Diabetic animals in groups 3-5 received ginger extract according to the dose stipulated in the table. Diabetic control animals in group 2 received neither distilled water nor the extract. All animals received either water or the extract through oral administration.

\section{Sample collection}

Fasting blood glucose level. Fasting blood glucose in blood was measured on days $0,7,15,21$ and 30 during the experiment with a glucometer. Intra- and inter-assay percentage $\mathrm{CV}$ using ten repeated measures and ten sessions were 1.89 and $4.30 \%$, respectively. Percentage reduction in blood glucose level was calculated as (BGC at $0 \mathrm{~d}-\mathrm{BGC}$ at $N$ day/ BGC at $0 \mathrm{~d}) \times 100$, where $\mathrm{BGC}=$ blood glucose concentration; and $N=$ treatment days.

\section{Collection of tissues}

Animals were anaesthetised by exposing them to diethyl ether in an air-tight chamber. Thereafter, they were dissected, and the liver, kidney and skeletal muscles were collected in precooled normal saline, and then blotted. Tissues were weighed and finally preserved with liquid $\mathrm{N}_{2}$ and frozen at $-80^{\circ} \mathrm{C}$ until used for the determination of metabolic changes.

\section{Sample preparation}

A small part of the liver tissue was cut and perfused with ice-cold $0 \cdot 15 \mathrm{M}-\mathrm{KCl}$ and $1 \mathrm{~mm}$-EDTA solution and homogenised with twice its weight of ice-cold buffer (0.01 cysteine and 1 mm-EDTA in $0.1 \mathrm{ml}$ Tris- $\mathrm{HCl}, \mathrm{pH} \mathrm{7.4}$ ) and centrifuged (at $20000 \mathrm{~g}$ ) for $20 \mathrm{~min}$ at $4^{\circ} \mathrm{C}$. The supernatant was filtered and frozen at $-80^{\circ} \mathrm{C}$. 
Table 2. Grouping of animals into five treatment groups

\begin{tabular}{lll}
\hline $\begin{array}{l}\text { Group } \\
\text { no. }\end{array}$ & Treatment & Description \\
\hline 1 & Distilled water & NCNT \\
2 & STZ $(65 \mathrm{mg} / \mathrm{kg})$ & DCNT \\
3 & STZ + ZO $(100 \mathrm{mg} / \mathrm{kg})$ & ZO $(100 \mathrm{mg} / \mathrm{kg})$-treated diabetic rats \\
4 & STZ + ZO $(300 \mathrm{mg} / \mathrm{kg})$ & ZO $(300 \mathrm{mg} / \mathrm{kg})$-treated diabetic rats \\
5 & STZ + ZO $(500 \mathrm{mg} / \mathrm{kg})$ & ZO $(500 \mathrm{mg} / \mathrm{kg})$-treated diabetic rats \\
\hline & NCNT, normal control rats; STZ, streptozotocin; DCNT, diabetic control rats; \\
ZO, Zingiber officinale. &
\end{tabular}

\section{Biochemical and enzymatic estimations}

Assay of glucokinase (EC 2712) activity. The liver glucokinase activity was measured at $340 \mathrm{~nm}$ in a reaction mixture

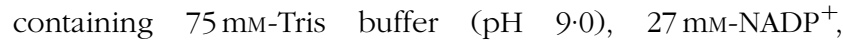

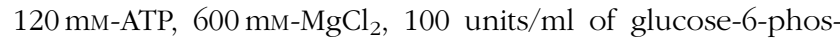
phate dehydrogenase and $360 \mathrm{~mm}$-glucose at $30^{\circ} \mathrm{C}$. Glucose phosphorylation was then assayed by means of the glucose6-phosphate-dependent spectrophotometric $\operatorname{method}^{(9)}$. The $\% \mathrm{CV}$ for this assay was $2.68 \%$ at $19 \cdot 40 \mathrm{U} / 1$ and $4.10 \%$ at $28.11 \mathrm{U} / 1$ for the intra- and inter-assay, respectively.

Assay of fructose-6-phosphate kinase (EC 27111) activity. Assay of fructose-6-phosphate kinase was carried out in a reaction mixture of $100 \mathrm{~mm}$-Tris buffer ( $\mathrm{pH} 8 \cdot 0), 40 \mathrm{~mm}$ and $140 \mathrm{~mm}$ of a mixture of $\mathrm{MgSO}_{4}-\mathrm{KCl}, 30 \mathrm{~mm}$-phosphoenol pyruvate solution, $20 \mathrm{~mm}$-fructose-1,6-diphosphate solution, $30 \mathrm{~mm}$-fructose-6-phosphate solution, $20 \mathrm{~mm}$-ATP, $7.0 \mathrm{~mm}-$ $\mathrm{NADH}$ and appropriately diluted pyruvate kinase (PK)/lactic dehydrogenase enzyme suspension. The fructose-6-phosphate kinase activity was assayed spectrophotometrically by the method of Racker ${ }^{(10)}$; and \%CV were 5.07 at $11.69 \mathrm{U} / 1$ and $5.39 \%$ at $8.30 \mathrm{U} / 1$ for the ten intra- and inter-assays.

Assay of pyruvate kinase (EC 27140) activity. The sample was added to a reaction mixture containing $100 \mathrm{~mm}$-potassium phosphate buffer, $\mathrm{pH} 7.6$ at $37^{\circ} \mathrm{C}, 1.3 \mathrm{~mm}-\mathrm{NADH}, 44 \mathrm{~mm}-\mathrm{ADP}$, $100 \mathrm{~mm}-\mathrm{MgSO}_{4}, 5000$ units/ml of lactic dehydrogenase and 17 mm-phosphoenol pyruvate freshly prepared. PK assays were then conducted with a thermostated recording spectrophotometer by coupling the enzyme activity to lactate dehydrogenase, using the procedure reported by Bergmeyer et al. ${ }^{(11)}$. Intra- and inter-assay $\% \mathrm{CV}$ using ten measurements were $4.57 \%$ at $9.77 \mathrm{U} / 1$ and $8.21 \%$ at $3.81 \mathrm{U} / 1$, respectively.

\section{Estimation of tissue glycogen level}

Tissue glycogen level was measured using the glycogen assay kit (Bio Vision) based on hydrolysis of glycogen to glucose by glucoamylases, which is then specifically oxidised to produce a product that reacts with oxy-red probe to generate a colour at $\lambda_{\max }=570 \mathrm{~nm}^{(12)}$. The precision as estimated by $\% \mathrm{CV}$ for intra- and inter-assay was 1.66 and $2.60 \%$, respectively, at $82.54 \mathrm{mg} / \mathrm{ml}$.

The protein contents of the tissue homogenates were estimated following the standard method of Lowry et al. ${ }^{(13)}$. Intra- and inter-assay $\% \mathrm{CV}$ were 7.74 and $11.05 \%$, respectively, at $6 \cdot 25 \mathrm{mg} / \mathrm{ml}$.

\section{Data and statistical analysis}

The data are presented as mean values with their standard deviations or errors. The statistical analysis was carried out using the software SPSS (version 11; SPSS, Inc.). Groups were compared using one-way ANOVA and Tukey's post hoc test was performed for multiple comparisons. Statistical significance was set at $P<0.05$.

\section{Results}

The safety limit $\left(L D_{50}\right)$ of ginger extract in rats

The percentage yield for the extract was $25 \cdot 3 \%(\mathrm{w} / \mathrm{w})$ as mentioned under 'Preparation of the rhizome extract'. The oral $\mathrm{LD}_{50}$ was estimated to be $4525.5 \mathrm{mg} / \mathrm{kg}$ in rats (Table 1), accordingly:

$$
\mathrm{LD}_{50}=(3200 \times 6400)^{1 / 2}=4525 \cdot 5 \mathrm{mg} / \mathrm{kg} .
$$

\section{Ginger reduced blood glucose levels in streptozotocin- induced diabetic rats}

The basal levels of blood glucose of the rats in all groups before STZ injection were not significantly different. However, $72 \mathrm{~h}$ after STZ injection, blood glucose levels were significantly higher in the STZ-induced rats. In contrast, normal control rats (NCNT) remained persistently euglycaemic throughout the course of the study (Table 3).

Table 3 also shows that ZO extract has dose-dependent antihyperglycaemic effect on the treated diabetic rats. Injection of STZ $(65 \mathrm{mg} / \mathrm{kg})$ led to over 4-fold elevation of blood glucose levels $(P<0.05)$ which were maintained over a period of 4 weeks in the DCNT. On the 7th day of treatment, DCNT showed a significant increase $(P<0.05)$ in blood glucose level as compared to NCNT. The ZO-treated (100, 300 and $500 \mathrm{mg} / \mathrm{kg}$ ) diabetic groups had their blood glucose significantly lowered $(P<0.05)$ when compared to DCNT, with $10 \cdot 63,25 \cdot 71$ and $25 \cdot 14 \%$ reduction, respectively, on the 7 th day. Again, there were significant reductions in blood glucose levels between the DCNT and (100, 300 and $500 \mathrm{mg} / \mathrm{kg}) \mathrm{ZO}-$ treated diabetic groups, with $10.69,38.05$ and $38.01 \%$ falls at the end of the 15th day, respectively, and $34.47,52.38$ and $53.26 \%$ falls at the end of the 21st day, respectively. After the 4 th week of daily treatment with the aqueous extract of $\mathrm{ZO}$, ginger led to a fall in blood glucose levels by 48.30 , 62.43 and $67.85 \%$ in the 100,300 and $500 \mathrm{mg} / \mathrm{kg}$-treated groups, respectively. The maximum antihyperglycaemic effect was observed in the $500 \mathrm{mg} / \mathrm{kg}$-treated group, which was not significantly different when compared with NCNT.

\section{Ginger improved body, liver and kidney weights of streptozotocin-induced diabetic rats}

Fig. 1 shows the effect of ZO extract $(500 \mathrm{mg} / \mathrm{kg})$ on body weight of STZ-induced diabetic rats. The diabetic control group (DCNT) did not gain any significant weight during the $30 \mathrm{~d}$ experimental period while NCNT and ZO 
(500 mg/kg)-treated rats gained significant weights $(P<0 \cdot 05)$. However, the increase in body weight in $\mathrm{ZO}(500 \mathrm{mg} / \mathrm{kg})$ treated rats was significantly lower than in NCNT $(P<0.05)$. When liver and kidney weights were expressed as percentages of body weight, there were observable variations. There was a significant increase in kidney weights of DCNT $(P<0.05)$ compared to NCNT, whereas kidney weights were found to be reduced significantly $(P<0.05)$ in $\mathrm{ZO}(500 \mathrm{mg} / \mathrm{kg})$-treated rats. Liver weight of DCNT showed a significant increase $(P<0.05)$ compared to NCNT, but this increase in the liver weight was not significantly altered $(P>0.05)$ by $\mathrm{ZO}$ $(500 \mathrm{mg} / \mathrm{kg})$ treatment as compared to the DCNT group (Table 4).

\section{Ginger lowered kidneys' glycogen content with no effect} on liver and skeletal muscle

Kidney glycogen content increased by over 10 -fold while liver and skeletal muscle glycogen content significantly $(P<0.05)$ decreased by 75 and $53 \%$ in DCNT $v$. NCNT. There was no significant difference in the glycogen content of liver and muscle in the ginger-treated diabetic group, although kidneys showed a significant decrease in glycogen content due to ginger treatment (Fig. 2).

\section{Ginger increased the activities of hepatic glycolytic enzymes in streptozotocin-induced diabetic rats}

The DCNT showed significant decrease by 94,53 and $61 \%$ in the activities of glucokinase, phosphofructokinase and $\mathrm{PK}$ (Fig. 3) compared to NCNT values; however, ZO (500 mg/ $\mathrm{kg})$ significantly $(P<0.05)$ increased these enzymes' activities when compared to DCNT.

\section{Discussion}

\section{Safety limit $\left(L D_{50}\right)$ of ginger extract in rats}

The high yield of the extract shows that optimal extraction of the constituents requires the use of polar solvents, in consonance with folkloric use of the aqueous infusions. The oral $\mathrm{LD}_{50}$ value of $4525.5 \mathrm{mg} / \mathrm{kg}$ in rats, obtained for the aqueous $\mathrm{ZO}$ extract falls within the practically non-toxic range ${ }^{(14)}$. The anti-hyperglycaemic effect observed for all doses $(100,300$ and $500 \mathrm{mg} / \mathrm{kg}$ ) tested was far below the minimum lethal dose $(4525 \cdot 5 \mathrm{mg} / \mathrm{kg})$. The acute toxicity test method by Lorke ${ }^{(8)}$ utilises a lower number of rats, usually thirteen, and provides a $24 \mathrm{~h} \mathrm{LD}_{50}$ value, which is adequate for most practical purposes. With the high margin of safety exhibited by the extract, higher doses can be used to achieve more pronounced anti-hyperglycaemic effect without sacrificing safety. This explains the widespread use of the plant extract in folklore medicine. Based on the results obtained, doses of 100, 300 and $500 \mathrm{mg} / \mathrm{kg}$ were selected for the anti-hyperglycaemic screening.

\section{Anti-hyperglycaemic effect of ginger in streptozotocin- induced diabetic rats}

Diabetes mellitus is characterised by chronic hyperglycaemia with disturbances of carbohydrate, fat and protein metabolism 


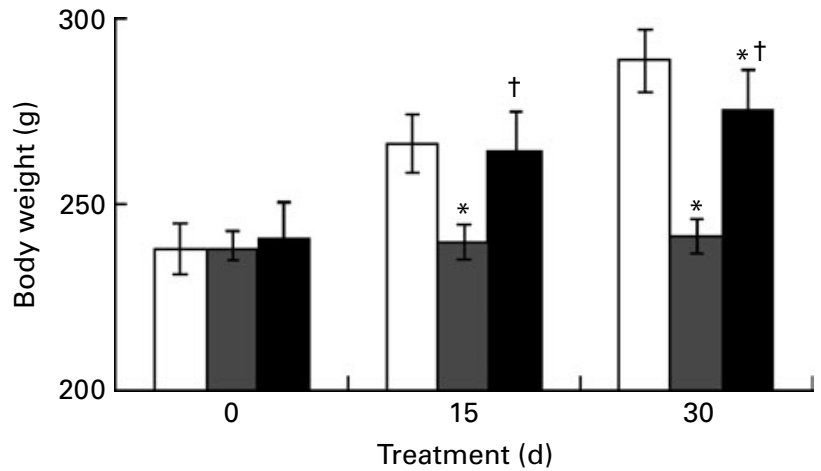

Fig. 1. Body weights of streptozotocin (STZ)-induced diabetic rats treated with an aqueous extract of ginger over the experimental period. Weights were measured in normal rats $(\square)$, STZ-induced diabetic rats $(\square)$ and ginger-treated STZ-induced diabetic rats $(500 \mathrm{mg} / \mathrm{kg}$ Zingiber officinale; $\boldsymbol{\square})$. The animals were weighed after STZ injection on 0,15 and $30 \mathrm{~d}$ of experimental period. Values are means, with their standard errors represented by vertical bars. * Mean value was significantly decreased compared with normal control at days 15 and $30 \quad(P<0.05)$. † Mean value was significantly different between diabetic control and ginger-treated diabetic rats $(P<0.05)$.

resulting from defects in insulin secretion, insulin action, or both. Strict control of the blood glucose level is considered to be essential in order to delay or prevent the development of diabetic complications ${ }^{(15)}$. Overt symptoms of diabetes mellitus include hyperglycaemia, increased water intake and polyuria ${ }^{(15)}$. Chronic complications can involve the kidneys (nephropathy), eyes, nervous system and cardiovascular system $^{(16)}$.

The anti-hyperglycaemic properties of ZO extract were investigated in the present study. STZ was selected as the diabetogenic agent because of its ability to selectively destroy the $\beta$-cells of the islet in the pancreas without direct injury to other tissues. A single intraperitoneal injection of $65 \mathrm{mg} / \mathrm{kg}$ of STZ in rats leads to hyperglycaemia, $72 \mathrm{~h}$ after the injection. The results indicated that the extract possessed significant anti-hyperglycaemic activities. The results also showed a dose-dependent decrease in the plasma glucose concentration from 16.39 (SD 1.97) to $5 \cdot 27$ (SD 0.67$) \mathrm{mmol} / \mathrm{l}(67.85 \%$ reduction), which corresponded with the maximum effect of $\mathrm{ZO}(500 \mathrm{mg} / \mathrm{kg})$ on the 30 th day.

Ginger contains potential bioactive compounds; mostly of volatile oils ${ }^{(17,18)}$. [6]-Gingerol is the most abundant bioactive pungent compound which has been consistently implicated as the antihyperglycaemic agent in ginger ${ }^{(19-21)}$. Ginger extract with a higher concentration of [6]-gingerol produces significant reduction in fructose-induced hyperglycaemia and hyperinsulinaemia when compared to another ginger extract with comparably lower concentration of [6]-gingerol ${ }^{(22,23)}$

Earlier studies of the hypoglycaemic properties of ginger in human subjects and animals have produced variable results. The administration of an ethanol extract of ginger (100 or $300 \mathrm{mg} / \mathrm{kg}$ ) to normal rabbits showed potential hypoglycaemic activity ( $51 \%$ decrease in serum glucose), $2 \mathrm{~h}$ after administration $^{(24)}$. In contrast, in another study, non-diabetic patients with coronary artery disease showed no decrease in their blood lipid or sugar levels when treated with a daily dose of $4 \mathrm{~g}$ powdered ginger for a period of 3 months ${ }^{(25)}$. The variability of the results in these studies may be due to the use of different ginger preparations, as it is noted that most of the studies in which anti-hyperglycaemic or hypoglycaemic effects of ginger were reported used ginger juice or water extract of ginger. However, recent studies have consistently reported the hypoglycaemic and antihyperglycaemic effects of ginger. Akhani et $a l .{ }^{(7)}$ have reported that ginger juice exhibits hypoglycaemic activity in both normal and STZ-induced diabetic rats. Al-Amin et al. ${ }^{(4)}$ also found that ginger possesses hypoglycaemic, hypocholesterolaemic and hypolipidaemic potential $^{(4)}$. They also showed that raw ginger is effective in reversing the diabetic proteinuria observed in diabetic rats. More recently, Asha et $a l .{ }^{(3)}$ and Jafri et $a l .{ }^{(26)}$ reported the antihyperglycaemic and hypoglycaemic activities of ginger in alloxan-induced diabetic rats. Clearly, the results in the present study confirm the observations in the recent studies pertaining to the glucose-lowering effect of ginger in blood. No previous studies have reported changes in tissue glycogen and the selected glycolytic enzymes involved in carbohydrate metabolism, as a result of ginger administration.

\section{Ginger ameliorates body, liver and kidney weights}

STZ-induced diabetes is characterised by severe loss in body weight $^{(27)}$ and this might be due to loss or degradation of structural proteins, as the structural proteins are known to contribute to body weight. In our study, during the experimental period, NCNT showed an approximately 20\% gain in body weight. On the other hand, DCNT showed no significant gain in body weight over the same time period. ZO-treated rats showed higher and significant gain in body weight in

Table 4. Effect of $30 \mathrm{~d}$ administration of Zingiber officinale (ZO) extract $(500 \mathrm{mg} / \mathrm{kg})$ on liver weight (LW) and kidney weight $(\mathrm{KW})$ in streptozotocin $(65 \mathrm{mg} / \mathrm{kg})$ diabetic rats

(Mean values with their standard errors)

\begin{tabular}{|c|c|c|c|c|c|c|c|c|}
\hline \multirow[b]{3}{*}{ Groups } & \multicolumn{4}{|c|}{ LW } & \multicolumn{4}{|c|}{$\mathrm{KW}$} \\
\hline & \multicolumn{2}{|c|}{ Absolute } & \multicolumn{2}{|c|}{$\mathrm{LW} / 100 \mathrm{~g} \mathrm{BW}$} & \multicolumn{2}{|c|}{ Absolute } & \multicolumn{2}{|c|}{$\mathrm{KW} / 100 \mathrm{~g} \mathrm{BW}$} \\
\hline & Mean & SEM & Mean & SEM & Mean & SEM & Mean & SEM \\
\hline NCNT & 8.53 & 0.06 & $2 \cdot 97$ & 0.08 & 1.77 & 0.06 & 0.62 & 0.03 \\
\hline DCNT & $8 \cdot 33$ & 0.07 & $3.47^{*}$ & $0 \cdot 14$ & 1.81 & 0.07 & $0 \cdot 76^{\star}$ & 0.03 \\
\hline ZO $(500 \mathrm{mg} / \mathrm{kg})$ & 8.83 & 0.10 & 3.23 & 0.12 & 1.89 & 0.09 & $0.69 \dagger$ & 0.00 \\
\hline
\end{tabular}

BW, body weight; NCNT; normal control rats, DCNT; diabetic control rats.

${ }^{*}$ Mean values were significantly different compared with NCNT $(P<0.05)$.

† Mean values were significantly different compared with DCNT $(P<0.05)$. 


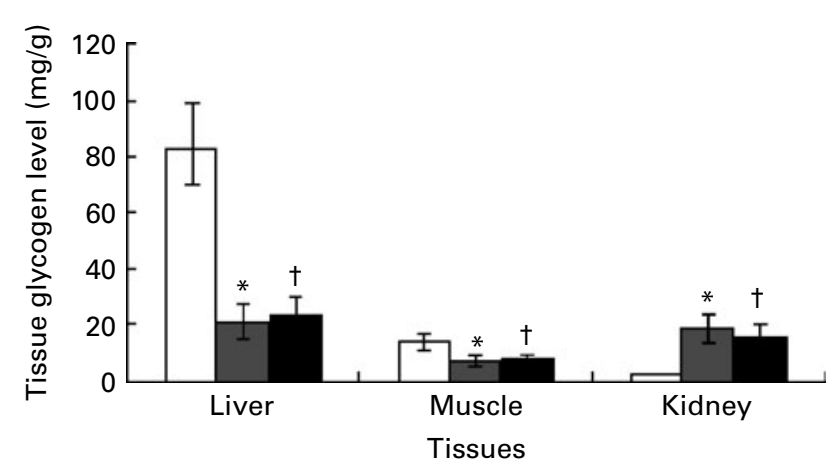

Fig. 2. Tissues' glycogen was estimated in streptozotocin (STZ)-induced diabetic rats treated with an aqueous extract of ginger over the experimental period. Tissues' glycogen in normal rats $(\square)$, STZ-induced diabetic rats $(\square)$ and ginger-treated STZ-induced diabetic rats $(500 \mathrm{mg} / \mathrm{kg}$ Zingiber officinale; $\mathbf{\square})$. Tissues' glycogen was estimated at the end of the experimental period. Values are means, with their standard errors represented by vertical bars. * Mean value was significantly different compared with normal control $(P<0.05)$. † Mean value was significantly decreased compared with diabetic control $(P<0.05)$.

comparison to DCNT. This gain in weight by ZO-treated rats showed in addition that ginger is effective in reversing the body weight loss observed in diabetic rats, which was earlier reported $^{(3,27,28)}$. STZ-induced diabetic animals tend to show renal hypertrophy. The entry of glucose in the renal tissue is not dependent on the action of insulin; therefore, in the event of hyperglycaemia, there is an increase in the entry of glucose $^{(29)}$. This has been hypothesised to cause increased intra-renal glycogen deposition, which leads to glycosylation of basement membrane collagen in the kidney ${ }^{(30)}$. This is reflected in the present finding as the diabetic rats showed approximately $20 \%$ increase in two-kidney $v$. body weight ratio in comparison to NCNT as well as more than 10-fold increase in renal glycogen content. Rise in renal weight as well as renal glycogen content has been reported previously $^{(30)}$ though in previous studies ${ }^{(31,32)}$ the degree of renal hypertrophy was much higher in comparison with the present study. The reason for this variation in the present and the past results can be attributed to the difference in the duration of the studies, i.e. 1 month $v .6$ and 2 months, respectively. ZO significantly lowered this renal hypertrophy (Table 4). Diabetic rats had significantly higher liver weight/ $100 \mathrm{~g}$ body weight and this alteration in the diabetics was not changed by treatment with ZO. The literature shows conflicting reports on the effect of diabetes on liver weight. While some studies report an increase in liver weight in animals ${ }^{(27,33,34)}$ as well as in human subjects ${ }^{(35)}$, a decrease and no change were also reported in $200 \mathrm{mg} / \mathrm{kg}$ alloxan-induced diabetes studied for $21 \mathrm{~d}^{(28,36)}$. The exact reasons of hepatic hypertrophy are not known. However, increased mobilisation and deposition of fat have been proposed to be the cause ${ }^{(35)}$.

\section{Ginger has no significant effect on liver and muscle but kidney glycogen content}

The liver plays an important role in buffering postprandial hyperglycaemia and is involved in the synthesis of glycogen. Glycogen is the primary intracellular storable form of glucose and its level in various tissues, especially skeletal muscle, is a direct reflection of insulin activity, as insulin promotes intracellular glycogen deposition by stimulating glycogen synthase and inhibiting glycogen phosphorylase. Since STZ causes selective destruction of $\beta$-cells of islets of Langerhans, resulting in marked decrease in insulin levels, it is rational that glycogen levels in insulin-dependent tissues (skeletal muscle and liver) decrease as they depend on insulin for the influx of glu$\operatorname{cose}^{(37-39)}$. Results showed that liver and skeletal glycogen content decreased drastically in DCNT by approximately three-quarters of their basal levels. This has also been reported earlier ${ }^{(40)}$. ZO showed a trend towards an increase in glycogen content but could not significantly increase the glycogen content in muscle and liver.

\section{Ginger increased the activities of hepatic glycolytic enzymes in streptozotocin-induced diabetic rats}

In the present study, the activities of glycolytic enzymes in the liver were significantly decreased $(P<0.05)$ in the DCNT. This confirms the previous findings ${ }^{(28,41,42)}$ that relative deficiency of insulin in the STZ model of type 1 diabetes causes suppression of glucokinase, phosphofructokinase and PK activities. These hepatic glycolytic enzymes are the regulatory factors which drive the metabolic degradation of glucose to form pyruvate. The high-energy compounds ATP and NADH are formed from the free energy released in this process. Maximum suppression was observed in hepatic glucokinase activity, followed by hepatic PK and phosphofructokinase activities. Administration of ZO extract increased significantly the activity of all the three enzymes towards NCNT, suggesting that the anti-hyperglycaemic action observed was as a result of increased glucose utilisation at the liver as well as skeletal muscle. However, it is not possible to deduce from the present findings that the increase in glycolytic enzymatic activity seen in the ZO-treated rats occurred secondary to the ZO-mediated release of insulin or whether a component of $\mathrm{ZO}$ had insulinomimetic action. Since STZ diabetes is an insulin-deficient

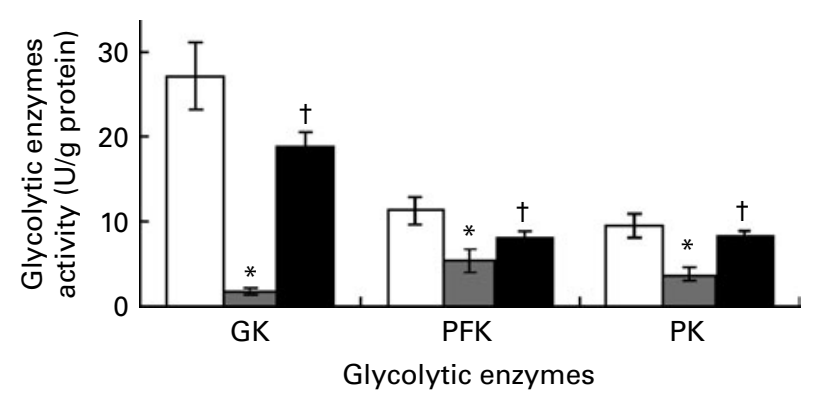

Fig. 3. Hepatic glycolytic enzymes' activity of streptozotocin (STZ)-induced diabetic rats treated with an aqueous extract of ginger over the experimental period was estimated. Enzymes' activity was measured in normal rats ( $\square$ ), STZ-induced diabetic rats $(\square)$ and ginger-treated STZ-induced diabetic rats $(500 \mathrm{mg} / \mathrm{kg}$ Zingiber officinale; $\mathbf{\square})$. Enzymes' activity was analysed at the end of the experimental period. Values are means, with their standard errors represented by vertical bars. * Mean value was significantly decreased compared with normal control $(P<0.05)$. †Mean value was significantly increased compared with diabetic control $(P<0.05)$. GK, glucokinase; PFK, phosphofructokinase; PK, pyruvate kinase. 
model, the likelihood of insulinomimetic effect seems more possible.

\section{Conclusion}

We have demonstrated that the folk medicinal plant ginger is practically non-toxic in rats, with the high margin of safety exhibited by the extract in the present study. The findings also suggest that the administration of $\mathrm{ZO}$ rhizome extract to diabetic rats gives good control over tissue glycogen content by enhancing the peripheral utilisation of glucose and correcting the impaired liver and kidney glycolysis and by limiting its gluconeogenic formation similar to insulin. Therefore, raw ginger has significant potential as a phytomedicine in the treatment of diabetes.

\section{Acknowledgements}

The present work was made possible through a research grant from the Research Endowment Fund, Research Management Centre (RMC), IIUM. The authors would like to thank Rafidah Hanim Mokhtar for the proof reading. There are no potential conflicts of interest in relation to this paper. N. B. A. carried out the majority of the biochemical analysis, designed the experiment and contributed to the writing. M. M. C. and N. N. W. contributed to the supervision and drafting of the manuscript. R. Z. and M. T. R. contributed with technical support, scientific advice and revised the manuscript.

\section{References}

1. Badreldin HA, Gerald B, Musbah OT, et al. (2008) Some phytochemical, pharmacological and toxicological properties of ginger (Zingiber officinale Roscoe): a review of recent research. Food Chem Toxicol 46, 409-420.

2. Chan SM, Nelson EA, Leung SS, et al. (2000) Special postpartum dietary practices of Hong Kong Chinese women. Eur J Clin Nutr 54, 797-802.

3. Asha B, Krishnamurthy KH \& Devaru S (2011) Evaluation of anti hyperglycaemic activity of Zingiber officinale (Ginger) in albino rats. $J$ Chem Pharm Res 3, 452-456.

4. Al-Amin ZM, Thomson M, Al-Qattan KK, et al. (2006) Antidiabetic and hypolipidaemic properties of ginger (Zingiber officinale) in streptozotocin-induced diabetic rats. Br J Nutr 96, 660-666.

5. Rang HP \& Dale MM (1991) The endocrine system. In Pharmacology, 2nd ed., pp. 504-508. Harlow: Longman Group Ltd.

6. Weidner MS \& Sigwart K (2000) The safety of a ginger extract in the rat. J Ethnopharmacol 73, 513-520.

7. Akhani SP, Vishwakarma SL \& Goyal RK (2004) Anti-diabetic activity of Zingiber officinale in streptozotocin-induced type I diabetic rats. J Pharm Pharmacol 56, 101-105.

8. Lorke DA (1983) A new approach to practical acute toxicity testing. Arch Toxicol 54, 275-287.

9. Crane RK \& Sols A (1955) Animal tissue hexokinases. In Methods in Enzymology, pp. 277-282 [SP Colowick and NO Kaplan, editors]. New York: Academic Press.

10. Racker E (1947) Spectrophotometric measurement of hexokinase and phosphohexokinase activity. J Biol Chem 167, 843-854.
11. Bergmeyer HU, Gawehn K \& Grassl M (1974) Pyruvate kinase from yeast. In Methods of Enzymatic Analysis, 2nd ed., vol. I, pp. 509-510. [HU Bergmeyer and K Gawehn, editors]. New York: Academic Press. Inc.

12. Huijing F (1970) Phosphorylase kinase deficiency. Biochem Genet 4, 187-194.

13. Lowry OH, Rosebrough NJ, Farr AL, et al. (1951) Protein measurement with the Folin phenol reagent. $J$ Biol Chem 193, 265-275.

14. Loomis JA (1978) Essentials of Toxicology, 3rd ed. Philadelphia. PA: Lea and Febiger.

15. White DA \& Baxter M (1994) Diabetes mellitus. In Hormones and Metabolic Control, 2nd ed., pp. 79-92 [DA White and M Baxter, editors]. London: Arnold.

16. Koda-Kimble MA \& Carlisle BA (1995) Diabetes mellitus. In Applied Therapeutics: The Clinical Use of Drugs, 6th ed., pp. 48-58 [LY Young, MA Koda-Kimble, WA Kradjan and BJ Guglielmo, editors]. Vancouver, BC: Applied Therapeutics, Inc.

17. Evans WC (2002) Pharmacopoeial and related drugs of biological origin. In Trease and Evans Pharmacognosy, 15th ed., pp. 277-280. Edinburgh: WB Saunders.

18. Van Wyk BE \& Wink M (2004) Medicinal Plants of the World. 1st ed. Briza: Pretoria.

19. Johji YM, Michihiko HQ, Rong M, et al. (1988) The anti-ulcer effect in rats of ginger constituents. J Ethnopharmacol 23, 299-304.

20. Wohlmuth H, Leach DN, Smith MK, et al. (2005) Gingerol content of diploid and tetraploid clones of ginger (Zingiber officinale Roscoe). J Agric Food Chem 53, 5772-5778.

21. Singh AB, Akanksha N, Singh R, et al. (2009) Antihyperglycaemic, lipid lowering and anti-oxidant properties of [6]-gingerol in $\mathrm{db} / \mathrm{db}$ mice. Int J Med Med Sci 1, 536-544.

22. Kadnur SV \& Goyal RK (2005) Beneficial effects of Zingiber officinale Roscoe on fructose induced hyperlipidemia and hyperinsulinemia in rats. Indian J Exp Biol 43, 1161-1164.

23. Goyal RK \& Kadnur SV (2006) Beneficial effects of Zingiber officinale on goldthioglucose induced obesity. Fitoterapia 77, 160-163.

24. Mascolo N, Jain R, Jain SC, et al. (1989) Ethnopharmacologic investigation of ginger (Zingiber officinale). J Ethnopharmacol 27, 129-140.

25. Bordia A, Verma SK \& Srivastava KC (1997) Effect of ginger (Zingiber officinale Rosc.) and fenugreek (Tringonella foenumgraecum L.) on blood lipids, blood sugar and platelet aggregation in patients with coronary artery disease. Prostaglandins Leukot Essent Fatty Acids 56, 379-384.

26. Jafri SA, Abass S \& Qasim M (2011) Hypoglycemic effect of ginger (Zingiber officinale) in alloxan induced diabetic rats (Rattus norvagicus). Pak Vet J 31, 160-162.

27. Chen V \& Ianuzzo CD (1982) Dosage effect of streptozotocin on rat tissue enzyme activities and glycogen concentration. Can J Physiol Pharmacol 60, 1251-1256.

28. Raju J, Gupta D \& Rao AR (2001) Trigonella foenumgraecum (fenugreek) seed powder improves glucose homeostasis in alloxan diabetic rat tissues by reversing the altered glycolytic, gluconeogenic and lipogenic enzymes. Mol Cell Biochem 224, 45-51.

29. Belfiore F, Rabuazzo AM \& Iannello S (1986) Anabolic response of some tissues to diabetes. Biochem Med Metab 35, $149-155$.

30. Anderson JW \& Stowring I (1973) Glycolytic and gluconeogenic enzyme activities in renal cortex of diabetic rats. $\mathrm{Am}$ J Physiol 224, 930-936. 
31. Rasch K (1980) Prevention of diabetic glomerulopathy in streptozotocin diabetic rats by insulin treatment albumin secretion. Diabetologia 18, 413-416.

32. Nielsen B, Gronbaek H, Osterby R, et al. (1999) The calcium channel blocker nitrendipine attenuates renal and glomerular hypertrophy in diabetic rats. Exp Nephrol 7, 242-250.

33. Murphy ED \& Anderson JW (1974) Tissue glycolytic and gluconeogenic enzyme activities in mildly and moderately diabetic rats: influence of tolbutamide administration. Endocrine 94, 27-34.

34. Sadique J, Chandra T, Thenmozhi V, et al. (1987) The antiinflammatory activity of Enicostemma littorale and Mullogo cerviana. Biochem Med Metab Biol 37, 167-176.

35. Van Lancker JL (1976) Cellular death and degeneration. In Molecular and Cellular Mechanism in Diseases, pp. 605-675 [JL Lancker, editor]. New York: Springer Verlag.

36. Gupta RK, Kesari AN, Murthy PS, et al. (2005) Hypoglycemic and antidiabetic effect of ethanolic extract of leaves of Annona squamosa L. in experimental animals. J Ethnopharmacol 99, 75-81.
37. Whitton PD \& Hems DA (1975) Glycogen synthesis in perfused liver of streptozotocin diabetic rats. Biochem J 150, 153.

38. Golden S, Wals PA \& Okajima F (1979) Glycogen synthesis by hepatocytes from diabetic rats. Biochem J 182, 727-734.

39. Bishop JS (1970) Inability of insulin to activate liver glycogen transferase D phosphatase in the diabetic pancreatectomized dog. Biochim Biophys Acta 208, 208-218.

40. Hikino H, Kobayashi M, Suzuki Y, et al. (1989) Mechanism of hypoglycemic activity of aconitan A, a glycan from Aconitum carmichaeli roots. J Ethnopharmacol 25, 295-304.

41. Grover JK, Vats V, Rathi SS, et al. (2000) Anti-hyperglycemic effect of Eugenia jambolana and Tinospora cordifolia in experimental diabetes and their effects on key metabolic enzymes involved in carbohydrate metabolism.J Ethnopharmacol 73, 461-470.

42. Rathi SS, Grover JK \& Vats V (2002) The effect of Momordica charantia and Mucuna pruriens in experimental diabetes and their effect on key metabolic enzymes involved in carbohydrate metabolism. Phytother Res 16, $236-243$. 